\title{
Influence of Compensation and Organizational Culture on Employee Performance: A Study on IT Firms of Dhaka, Bangladesh
}

\author{
Afdalin Bin Haque (Corresponding author) \\ Asst. Professor, Dept. of Management, American International University-Bangladesh \\ 408/1, Kuratoli, Khilkhet, Dhaka 1229, Bangladesh \\ E-mail: afdalinhaque@yahoo.com; afdalinpial@aiub.edu
}

Md. Arif Al Mahmud

Associate Monitoring and Documentation Officer, UNHCR Project (Rohingya Response)

Kabir Guest House ( $3^{\text {rd }}$ Floor), Hotel Motel Zone, Kalatali, Cox’s Bazar, Bangladesh E-mail: arifm797@gmail.com

Adnan Hossain

Asst. Professor, Dept. of Management, American International University-Bangladesh 408/1, Kuratoli, Khilkhet, Dhaka 1229, Bangladesh

E-mail: adnan_leader15@yahoo.com

Received: May 30, 2019 Accepted: June 24, 2019 Online published: June 8, 2019

doi:10.5296/ijhrs.v9i3.15048ＵRL: https://doi.org/10.5296/ijhrs.v9i3.15048

\begin{abstract}
This paper aims to investigate the influence of Employee Compensation inclusive of Salary, Rewards and Incentives, Indirect Compensation and also Organizational Culture on the employee performance of the IT firms based on Dhaka, Bangladesh. A total of 204 employees of different IT firms of Dhaka were randomly selected as sample of the study responding to a structured questionnaire. The study incorporated Pearson Correlation and Multiple Regression analysis to analyze the data. The results exhibit the relationship and also
\end{abstract}


demonstrate the impact of total compensation of employees and organizational culture on employee performance. The core findings of this study will benefit the user especially from the IT sector to identify the factors that increase the performance level of any IT personnel as the cumulative employee performance is the organization's performance. The study is to be the first to explore the impact of Compensation and Organizational Culture on Employee performance in urban context of Bangladesh.

Keywords: compensation, employee performance, indirect compensation, organizational culture, rewards and incentives, salary

\section{Introduction}

Employees are the most significant asset of any organization. Now a day, employee's performance is one of the vital issues for organizations. Now, it is proved that employees can make the organization more effective and help to research the strategic goals in competitive corporate market. Human resource management theories mainly operate to find out the effectiveness of employee performance. In this study human resource elements have been evaluated with its impact on the performance of employees of IT industry of Bangladesh. The elements include Employee's Total Compensation and Organizational Culture. "If organizations practice standard compensation package according to human resource strategic theories such as maintaining employee's monetary, non-monetary benefits the employee's will be motivated to perform better in organization (Ivancevch and Glueck, 1989)". Therefore, the employee turnover rate is increasing day by day. Due to employee's performance problem organizations are losing their productivity and industry is being affected. Actually must be identified that financial benefits or compensation can be good or in times primary motivational factor to enhance the employee's performance in the IT Industry. Ritchie (2000) defined that the organizational culture is a motivational factor that ensure the employee's better performance. Further studies also demonstrated the impact of organizational culture on employees' performance, for instance, Tichy (1982) claimed, the normative glue based upon organizational culture helps in holding overall management effectiveness. Furthermore, scholars (Hofstede and Bond, 1988) have emphasized on the use of culture as an effective tool for measuring economic performance of an organization. The study intends to evaluate the joint impact of total compensation and organizational culture on employees' performance. Furthermore, the study is focused on the IT industry personnel as information technology is now a sector that is indispensable for global development. Therefore, it is imperative to assess the level of motivation and performance of the workforce working in this industry.

\section{Literature Review}

\subsection{Employee Performance}

Performance comprises the event or events where one group of people (performers) performs in a particular way for another group of people or any organization. Hellriegel, Jackson and Hellriegel et. al. (2005) defined that performance is an individual's work accomplishment after the application of his or her effort. Task Performance are the actions that contribute to transforming raw materials to goods and services, the things that are typically included in job 
descriptions. According to Calvin (2017) Performance can further be broken down into two distinct types: Task Performance and Contextual performance. Task Performance are the actions that contribute to transforming raw materials to goods and services, the things that are typically included in job descriptions. Examples include selling clothes, drilling holes, or teaching a class. Contextual performance are the behaviours that contribute to overall effectiveness through supporting the social and psychological climate of the workplace.

As a concept, employee performance can be referred as output measures such as productivity, product and service quality, and employee turnover (Dyer and Reeves, 1995; Boselie, Dietz and Boon, 2005, cited in Baptiste, 2008). Actually, employee's performance is an effort to help the organization to achieve the organization goals and objectives. Campbell, McHenry and Wise (1990) refers that employee's performance is a behaviour. It's the difference between performance and outcomes, individual's work defined by the outcomes although the results has others effects. Another way, Boddy et. al. (2009) defines the performance is a result of activities. Barifaijo et. al. (2009) also refers that performance is a thing which an organization through an individual's performance helps to achieve the mission and deliver the service in proper way to meet the stakeholders' desire. Nazir and Islam (2017) acknowledge that employee performance as well as commitment will not be efficient if the organization does not provide proper motivation to increase that performance level.

Therefore, it can be claimed that, Employee's performance is an accomplishment of certain work to measure against the benchmark of standard level, cost speed. Regarding an employment contract with the organization, employee's performance is an achievement of commitment with organization in such kind of output that the employees release from all kinds of liabilities under the employment contract

\subsection{Employee Salary}

Heathfield, (2019) defines that, employee salary is a fixed amount of money or compensation paid to an employee by an employer for his or her given productive performance. Basic salary is a fixed periodical payment for non-manual employees usually expressed in annual terms, paid per month with generally no additions for productivity. Wage refers to payment to manual workers, always calculated on hourly or piece rates. (Braton and Gold, 2017). Therefore, salary is a periodic regular employee's compensation during employment time. The periodic system may be paid in any frequency range but normally the employee's salary paid on monthly not hourly, daily, weekly and piece work systems basis and most of organization basically follow monthly basis system. In this study, the base salary is regarded as the initial monetary rewards which is obtained by and employee at the end of every month and it does not include other compensation.

\subsection{Rewards}

Reward is the benefits that arise from performing a task, rendering a service or discharging a responsibility (Pitts, 1995). In another way Malhotra et. al. (2007) believes that employees receives level of rewards, tangible benefits in their employment period is called rewards. There is no doubt that every employee deserves a minimum level of reward from their 
organization. Employees normally expect that their employers will ensure minimum level of rewards for their motivation and the level of rewards will be increased based on their performance. Hence, rewards are any monetary or non-monetary value that is offered to an employee in exchange of his or her service rendered to the organization.

\subsection{Incentives}

Incentives are defined as a technique that every employee get from their organization under their compensation package system during their employment (Hartman, Kurtz and Moser, 1994). Incentives can be tangible and intangible which is applied to motivate the employees to enhance their performance in specific way within the organization (Burkhauser, Bronte-Tinkew and Kennedy, 2008). On the other hand, Luthans (2011) defines that the monetary incentives and non-monetary incentives has another name which is financial and non-financial incentives. Generally, it can be paid based on employees' daily performance which helps to reach the organization's goals. Incentives are totally different than employee's basic salary, wages and other financial benefits and employees can achieve it by their exceptional performance, (Martocchio, 2011). Thus, the incentives are generally regarded as any additional monetary or non-monetary benefits offered to an individual employee apart from the base pay or any other rewards beside the prescribed structure.

\subsection{Indirect Compensation}

Dessler (2015) defines that the indirect compensation is the monetary and non-monetary payment for the employees during their employment with the organization and it is very vital part of the employee's compensation system. Armstrong (2016) refers that employee's indirect compensation or indirect benefits program can be given to the employees in various way of cash but did not suggest to include annual holidays in indirect compensation as an indirect benefit to employees. Organizations use it as a recruitment program effort to encourage the employees to become potential employees and come to workplace for joining the work and also encourage to become committed with the organization, to decrease the absenteeism of employees' and developing organization's strength by establishing the program (Noe et. al., 2013). Another way Chhabra (2005) define that Indirect compensation is a fringe benefits which are given to the employees and the indirect compensation includes housing rent, medical insurance, food, perks and others benefits. That kinds of reward organization gives to their employees for their employment with organization, contributions, attendance, and performance in the organization. The main reason of using indirect compensation is to attract the employees to stay with organization and motivate them to work in the organization effectively. There are some types of popular and effective indirect compensation program which are used in organization very frequently (Rue et. al., 2016). That are, Paid Holiday, Worker's compensation, Social security, Retirement benefits, Paid vacation and other benefits.

\subsection{Organizational Culture}

Schein (2010) states that organizational culture is set of employees values, norms, culture, believes, working style, attitudes what employees are demanded from their organization in 
work place. Organizational culture is a force which will reward the employee's contribution talent and also provide direction how to do the work, how the organization's goals and objectives are interrelated and how the employees will achieve the goals. This concept keeps the employees in line with the organization objectives. According to Martins and Terblanche (2003) organizational culture carries high level of values and beliefs and it is developed by the organization.

\subsection{Salary Performance Relationship}

Employee's salary is a very significant factor to trend the employee's performance in organization and it has also influence power on employee's decision whether they stay or leave in the organization (Kline and Hsieh, 2007). To strengthen the idea Lazear (1999) also agreed with that and believed that performance based workers earn more than ordinary workers. For example, when a firm see their production increasing, then the employee's payment system change monthly salary to daily basis wages, which indicates the wages payment system have direct impact on employee's performance. Employee's salary mainly ensure the employee's job security and performance can create a good competition among the employees in organization. After this, employees will be motivated and prove their talent by showing their performance in work place. Therefore, the hypotheses established would be:

$\mathrm{H} 1 \mathrm{l}=$ There is a positive relationship between employees salary and employees performance.

\subsection{Reward, Incentive and Performance Relationship}

Identifying the accurate tangible and intangible rewards to enhance the employees' motivation is very difficult task for any kind of organization. Professional HR leaders need this process to understand the organization needs and to create the reward strategies which is lead to enhancement the employee's performance perfectly. According to DeMatteo et. al. (1998) combination of reward system process can be applied for increasing employees' performance and also team work together.

Serious employees who are always dedicated to their respective organizations and are career oriented are a big part of the organization since those kinds of the employees act like an engine of the organization and helps to drive towards the right path and as such should be rewarded. Malhotra et. al. (2007) believes that it does not matter what kind of organization it is, the matter is rewards can play a vital role in building and maintaining committed employees in organization and ensure the high standard of performance for the organization. Finally, rewards make the employees more motivated to do their work willingly and also help the organizations to enhance the productivity.

Adequate incentives helps the employees to be motivated and enhance their performance in organization. Incentive strategies can be aligned in compensation package that can help to increase an employee's performance than normal estimated standard (Schiller, 1996). Organization can use any kind of incentives for employees' performance but for the effective results organization needs to analyse incentives criteria which are best for its employees. Extrinsic motivation needs external incentives. Extrinsic motivation define by the tangible incentives like employees salary, wages, cash payment, paid vacation, air tickets, movie 
tickets, fringe benefits and others tangible incentives can be extrinsic motivation. Pattanayak (2014) states that the intrinsic and extrinsic incentives are the most vital factors to enhance the employee's motivation, commitment and satisfaction of the employee's job in organization or work place. The non-monetary incentives can be used as motivational instruments for both intrinsic extrinsic motivation concepts.

$\mathrm{H} 2$ = There is a strong positive relationship between employee reward incentives and employees performance.

\subsection{Indirect Compensation Performance Relationship}

According to Tsai and Wang, (2005) to retain and attract high performers and competitive employees in the company compensation is quite a big help. And it is significantly evident from their research that, Indirect Compensation plays a fundamental role. Indirect compensation play a moderating role and increase the positive impact of Labour input on an organization's output with the retention and recruitment of high quality employees (Ahmed and Ahmed, 2014). Golung (2013) has also emphasised on the impact of indirect compensation on employee performance. The different mode of indirect compensation has also implication on employee motivation and feel for his or her work. Thus, the hypothesis supporting this study would be:

$\mathrm{H} 3=$ There is a positive relationship between indirect compensation and employees performance.

\subsection{Culture Performance Relationship}

Many researchers such as Hofstede et. al. (1990), Rousseau et. al. (1998), Smircich (2017) and Louis (1981) believe that organizational culture mainly is holistic and socially developed concept by the organization's members and its few features can measure its effect on the employee's performance. According to Kim et. al. (1995) organizational culture is a core element and has impact on the overall organization's effectiveness and helps to produce quality goods and service. Slocum and Hellriegel (2011) believe that organizational culture helps to increase the employee's performance if the organization can identify the right culture for it. Based on which it clarifies that, organizational culture tend the organization towards the right direction and the drive to follow the same culture and same style brings the level performance from organization's employees. However, as culture is the shared system based on mutual understanding and communication of the organization, if the organizational culture is unable to meet desired level of these functions, the organizational culture may have negative effect on employees' performance as well as organizations performance (Furnham and Gunter, 1993). On the contrary according to Daft (2013) a strong organizational culture enhance the employee's performance by the employees motivation according to organization goals and objectives and at last force the employees behaviour to the right direction at the higher level operational and functional strategies. By emphasising more, researchers like Messner (2013) has included employee performance orientation in organisational culture which displays the strong relationship between employee performance and organizational Culture. 
$\mathrm{H} 4=$ There is a positive relationship between organizations culture and employees performance.

\subsection{Theoretical Framework}

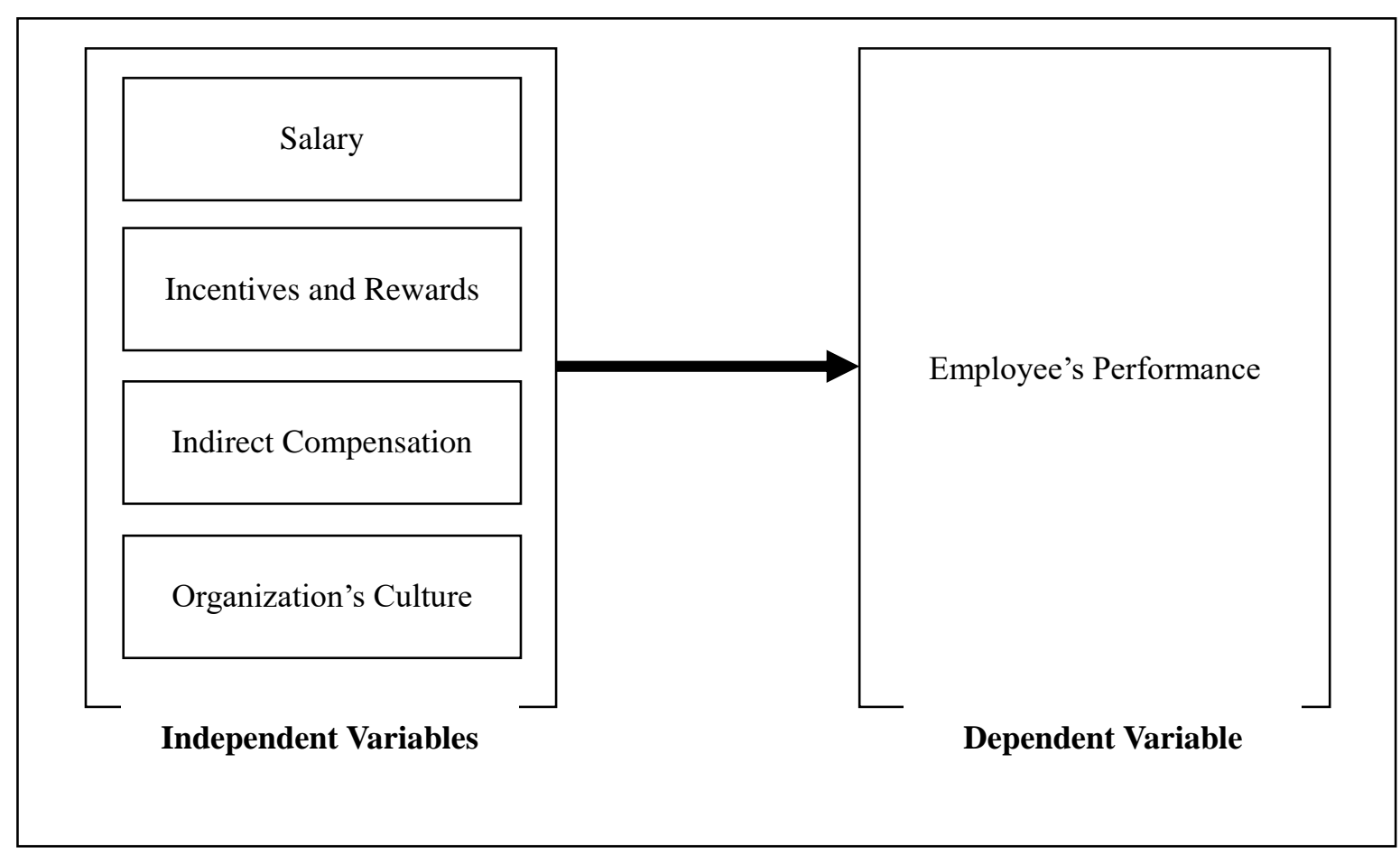

Figure 1. The theoretical framework

The figure embodies the theoretical framework by displaying the relationships between independent and dependent variable.

\subsubsection{Independent Variables}

Independent variables can be defined as those variables which are not reliant or biased on other variables. In this research, four independent variables has been defined such as, employee's salary, incentives and rewards, indirect compensation and organizational culture.

\subsubsection{Dependent Variable}

Dependent variables can be defined those variables which are influence by the other variables especially, independent variables. In this paper there is only one dependent variable and that is employee's performance.

\section{Research Methodology}

The study used primary data source and the survey questionnaire with five point Likert scale. A sample size of 204 respondents responded to the structured questionnaire. The quantitative method has been used to analysis the data as an analysis tools and descriptive statistics is used to describe and interpret the results. Pearson correlation coefficient is used to measure the degree of association between independent and dependent variables. For hypothesis testing multiple regression analysis is used in this study. Statistical Package for the Social 


\section{Ml Macrothink}

International Journal of Human Resource Studies

ISSN 2162-3058

2019, Vol. 9, No. 3

Science (SPSS) has been used to analyse the selected data as a standard tool. Pearson Correlation and Multiple Regression analysis has been applied to draw the accurate results of this study.

\section{Results and Discussion}

\subsection{Pearson Correlation Analysis}

Table 1. Pearson Correlation Analysis

\begin{tabular}{|c|c|c|c|c|c|}
\hline & \begin{tabular}{|c|} 
Employee \\
salary
\end{tabular} & $\begin{array}{l}\text { Incentives } \\
\text { \& rewards }\end{array}$ & $\begin{array}{c}\text { Indirect } \\
\text { compensation }\end{array}$ & $\begin{array}{l}\text { Organization } \\
\text { culture }\end{array}$ & $\begin{array}{c}\text { Employee } \\
\text { performance }\end{array}$ \\
\hline Pearson Correlation & 1 & $.691^{* *}$ & $.597^{* *}$ & $.613^{* *}$ & $.674^{* *}$ \\
\hline $\begin{array}{lll}\begin{array}{l}\text { Employee } \\
\text { (2-tailed) }\end{array} & \text { salary } \\
\end{array}$ & & .000 & .000 & .000 & .000 \\
\hline $\mathrm{N}$ & 204 & 204 & 204 & 204 & 204 \\
\hline Pearson Correlation & $.691^{* * *}$ & 1 & $.651^{* *}$ & $.632^{* *}$ & $.619^{* *}$ \\
\hline $\begin{array}{l}\text { Incentives } \\
\text { and rewards } \quad \text { Sig.(2-tailed) }\end{array}$ & .000 & & .000 & .000 & .000 \\
\hline $\mathrm{N}$ & 204 & 204 & 204 & 204 & 204 \\
\hline Pearson Correlation & $.597^{* *}$ & $.651^{* *}$ & 1 & $.737^{* *}$ & $.622^{* * *}$ \\
\hline $\begin{array}{l}\text { Indirect } \\
\text { Compensation Sig. } \\
\text { (2-tailed) }\end{array}$ & .000 & .000 & & .000 & .000 \\
\hline $\mathrm{N}$ & 204 & 204 & 204 & 204 & 204 \\
\hline Pearson Correlation & $.613^{* *}$ & $.632^{* *}$ & $.737^{* *}$ & 1 & $.713^{* *}$ \\
\hline $\begin{array}{l}\text { Organization } \\
\text { culture } \\
\text { (2-tailed) }\end{array}$ & .000 & .000 & .000 & & .000 \\
\hline$\overline{\mathrm{N}}$ & 204 & 204 & 204 & 204 & 204 \\
\hline Pearson Correlation & $.674^{* *}$ & $.619^{* *}$ & $.622^{* *}$ & $.713^{* *}$ & 1 \\
\hline $\begin{array}{l}\text { Employee } \\
\text { performance } \\
\text { (2-tailed) }\end{array}$ & .000 & .000 & .000 & .000 & \\
\hline$\overline{\mathrm{N}}$ & 204 & 204 & 204 & 204 & 204 \\
\hline
\end{tabular}

** Correlation is significant at the 0.01 level (2-tailed).

The Table 1 presents the correlation analysis of the research variables employee's salary, incentives and rewards, indirect compensation, organizational culture and employee's performance and the relationship among these variables is given below.

\subsubsection{Employee's Salary- Employee's Performance}

The table result indicates strong positive relationship between employee's salary and employee's performance as Pearson $r$ is +0.674 . The significant positive linear relationship indicates if there is an increase in employee salary employee performance would increase. 


\section{Mll Macrothink}

International Journal of Human Resource Studies

ISSN 2162-3058 2019, Vol. 9, No. 3

\subsubsection{Incentives and Rewards - Employee's Performance}

Although not strong but an above moderate relationship between incentives and rewards as well as employee performance has been observed, which implies, an increase in incentives and rewards would result in better performance of the employees.

\subsubsection{Indirect Compensation - Employee's Performance}

Similar results are found in relationship between indirect compensation and employee performance. However, the level of association is stronger than the association between incentives and rewards as well as employee performance. Such positive linear relationship urges for an effective indirect compensation to improve employee performance.

\subsubsection{Organizational Culture - Employee's Performance}

The table result indicates a very strong positive relationship between organizational culture and employee's performance ( $\mathrm{r}$ value) as Pearson $r$ is +0.713 . It means organizations employee's performance depends on standard organization practice and the stronger the culture becomes, performance enhances significantly. Thus, there is direct relationship between these variables.

\subsection{Multiple Regression Analysis}

Table 2. Coefficient Table (Multiple Regression)

\begin{tabular}{|c|c|c|c|c|c|c|}
\hline & \multirow[b]{2}{*}{ Model } & \multicolumn{2}{|c|}{$\begin{array}{c}\text { Unstandardized } \\
\text { Coefficients }\end{array}$} & \multirow{2}{*}{\begin{tabular}{|c} 
Standardized \\
Coefficients \\
Beta \\
\end{tabular}} & \multirow[b]{2}{*}{$\mathrm{t}$} & \multirow[b]{2}{*}{ Sig. } \\
\hline & & B & $\begin{array}{l}\text { Std. } \\
\text { Error }\end{array}$ & & & \\
\hline \multirow[t]{5}{*}{1} & (Constant) & -1.707 & 1.153 & & -1.480 & .140 \\
\hline & Employee salary & .515 & .107 & .314 & 4.813 & .000 \\
\hline & Incentives \& rewards & .154 & .106 & .099 & 1.448 & .149 \\
\hline & $\begin{array}{c}\text { Indirect } \\
\text { compensation }\end{array}$ & .056 & .055 & .071 & 1.009 & .314 \\
\hline & Organization culture & .271 & .047 & .405 & 5.754 & .000 \\
\hline
\end{tabular}

a. Dependent Variable: Employee performance

The Table No. 2 exhibits the impact of the independent variables (employee salary, incentives and rewards, indirect compensation and organizational culture) on dependent variable (employee's performance) and the impact is given below.

\subsubsection{Employee Salary}

The table coefficient information present that the significance of employee salary is 0.000 which is less than $0.05(0.000<0.05)$. So, it is evident that there is a positive significant relationship between employee's salary and employee performance. Which indicates the impact of Employee salary on employee performance. 


\subsubsection{Incentives and Rewards}

The table shows that incentives and rewards significance is 0.149 which is greater than 0.05 (0.149>0.05) which confidently implies that change in Incentives and Rewards provided to employees should not have significant impact on employee performance.

\subsubsection{Indirect Compensation}

The findings of the table for indirect compensation projects similar results as the incentives and rewards where the significance is greater than standard value (0.05) of this variable, (0.314> 0.05). Therefore, similarly it can be concluded that the impact of Indirect Compensation on employee performance is notably insignificant.

\subsubsection{Organizational Culture}

Unlike previous two independent variables the organizational culture rather shows positive results. Whilst Incentive and Rewards, and indirect compensation has insignificant impact on employee performance, organizational culture shows a significance level lower than the standard value of $0.05 \quad(0.000<0.05)$ and thus it demonstrates the significant impact organizational culture should have on employee performance.

\subsubsection{Equation for the regression analysis}

Employee performance $=-1.707+0.515$ (employee salary) -0.154 (incentives and rewards) -0.056 (indirect compensation) +0.271 (organizational culture) .

\subsection{Hypothesis Testing}

Table 3. Hypothesis Testing

\begin{tabular}{|c|c|c|c|}
\hline Research questions & Hypothesis & $\mathrm{P}$ - value & Result \\
\hline Question - 1 & $\begin{array}{l}\text { H1: There is a positive relationship between } \\
\text { employees salary and employees } \\
\text { performance. }\end{array}$ & $\begin{array}{l}P=0.000 \\
\beta=0.515\end{array}$ & $\begin{array}{l}\text { Accept } \\
\text { H1 }\end{array}$ \\
\hline Question - 2 & $\begin{array}{l}\text { H2: There is a positive relationship between } \\
\text { employee reward \& incentives and employees } \\
\text { performance. }\end{array}$ & $\begin{array}{l}P=0.314 \\
\beta=0.056\end{array}$ & $\begin{array}{l}\text { Reject } \\
\mathrm{H} 2\end{array}$ \\
\hline Question - 3 & $\begin{array}{l}\text { H3: There is a positive relationship between } \\
\text { indirect compensation and employee's } \\
\text { performance. }\end{array}$ & $\begin{array}{l}P=0.149 \\
\beta=0.154\end{array}$ & $\begin{array}{l}\text { Reject } \\
\text { H3 }\end{array}$ \\
\hline Question - 4 & $\begin{array}{l}\text { H4: There is a positive relationship between } \\
\text { organizations culture and employees } \\
\text { performance. }\end{array}$ & $\begin{array}{l}P=0.000 \\
\beta=0.271\end{array}$ & $\begin{array}{l}\text { Accept } \\
\text { H4 }\end{array}$ \\
\hline
\end{tabular}

\subsubsection{Analysis of Hypothesis Results}

Hypothesis 1: There is a positive relationship between employee salary and employee's 
performance.

The hypothesis 1 is accepted based on the $\mathrm{P}$ value where alpha value is less than alpha value $(0.000<0.05)$. Therefore, the table indicates that employee's salary has positive impact on employee's performance and it is significantly proved in this research. According to H1 results a standard and employee's expected salary helps to enhance employee's performance and organizational productivity indeed.

Hypothesis 2: There is a positive relationship between incentives and rewards and employee performance.

The tables $\mathrm{P}$ value $(0.314>0.05)$ indicates that hypothesis 2 is rejected in this study. So, there is no direct impact of employee's incentives and rewards on employee's performance. Although the $\mathrm{H} 2$ is rejected but employee's incentives and rewards is a core part of standard employee's compensation package and organization management should practice it because incentives and rewards help to motivate the employees to do their job properly.

Hypothesis 3: There is a positive relationship between indirect compensation and employee performance.

The tables $\mathrm{P}$ value $(0.149>0.05)$ also indicate that hypothesis 3 is rejected in this study. So, there is no direct impact of indirect compensation on employee's performance. Although the $\mathrm{H} 3$ is rejected but employee's indirect compensation is also a core part of standard employee's compensation package and organizations management should establish indirect compensation in employee's compensation package.

Hypothesis 4: There is a positive relationship between organizational culture and employee performance.

Hypothesis 4 is accepted based on the P value and standard alpha value is greater than $\mathrm{H} 4$ 's $\mathrm{P}$ value, $(0.000<0.05)$. Therefore, the following $\mathrm{H} 4$ table refers that organizational culture has significant impact on employee's performance. The hypothesis results proved that a standard and innovative organizations culture influence the employee's performance as well as organizations productivity.

\section{Conclusion}

The IT industry is becoming one of the strong sources of intellectual earnings in Bangladesh. The country is having the highest number of IT personnel than ever. When it comes to the productivity and performance of the organization, it is always of highest priority to identify the factors that foster higher performance. This paper demonstrated that employee's salary and organizational culture have positive significant impact on employee's performance and the paper also has mapped out employee performance due to competitive compensation package and innovative organizational culture practice. The IT industry is though urbanized in Bangladesh right now, the results keep scope for further exploration of changes in findings as the need for performance in global and the higher performance is likely to be dependent on the return employees receive. If and when applied, a good salary structure and a healthy work culture will certainly result into higher organizational performance. 


\section{I Macrothink}

International Journal of Human Resource Studies ISSN 2162-3058 2019, Vol. 9, No. 3

Since, the study exhibits the impact of Compensation and Organizational Culture on the Performance of IT Personnel working in Bangladesh, it explores further scope of research actions to be undertaken to extend the existing findings to further analysis. The paper contributes in the performance management aspects of IT industry, thus the users shall be aided to utilize the findings to enhance the employee performance by not only ensuring proper compensation but promoting a precise organizational culture also. The paper shall serve the needful, especially the human resource rendering service to the IT industry of Bangladesh.

\section{References}

Ahmed, M., \& Ahmed, A. B. (2014). The Impact of Indirect Compensation on Employee performance: An Overview. Public Policy and Administration Research, 4(6), 27-30.

Armstrong, M. (2016). Armstrongs handbook of strategic human resource management (6th ed.). London: KoganPage.

Baptiste, N. R. (2008). Tightening the link between employee wellbeing at work and performance. Management Decision, 284-309. https://doi.org/10.1108/00251740810854168

Barifaijo, M., Nkata, J., \& Ssempebwa, J. (2009). Human Resource Management Relate d Facto rs Affecting Performance among Part-time Academic Staff in Ugandan Public Universities. Makerere Journal of Higher Education, 2(1). https://doi.org/10.4314/majohe.v2i1.46399

Boddy, D., Boonstra, A., \& Kennedy, G. (2009). Managing information systems: Strategy and organisation. Harlow: Prentice Hall Financial Times.

Boselie, P., Dietz, G., \& Boon, C. (2005). Commonalities and contradictions in HRM and performance research. Human Resource Management Journal, 15(3), 67-94. https://doi.org/10.1111/j.1748-8583.2005.tb00154.x

Bratton, J., \& Gold, J. (2017). Human resource management: Theory and practice (6th ed.). London: Palgrave Macmillan. https://doi.org/10.1057/978-1-137-58668-1

Burkhauser, M., Bronte-Tinkew, J., \& Kennedy, E. (2008). Building community partnerships: tips for out-of-school time programs. Child Trends, 13(8). https://doi.org/10.1037/e456972008-001

Calvin, O. Y. (2017). The Impact of Remuneration on Employees Performance : A Study of Abdul Gusau Polytechnic, Talata-Mafara and State College of Education Maru, Zamfara State. Nigerian Chapter of Arabian Journal of Business and Management Review, 4(2), 34-43. https://doi.org/10.12816/0037554

Campbell, J. P., Mchenry, J. J., \& Wise, L. L. (1990). Modeling Job Performance In A Population Of Jobs. Personnel Psychology, 43(2), 313-575. https://doi.org/10.1111/j.1744-6570.1990.tb01561.x 
Chhabra, T. N. (2005). Human resource management: Concepts and issues (2nd ed.). Delhi: Dhanpat Rai \& (P).

Daft, R. L. (2013). Understanding theory and design of organizations (11th ed.). Australia: South Western, Cengage Learning.

DeMatteo, J. S., Eby, L. T., \& Sundstrom, E. (1998). Team-based rewards: Current empirical evidence. Research in organizational behavior, 20, 141-183.

Dessler, G. (2015). Human resource management (14th ed.). Boston: Pearson.

Dyer, L., \& Reeves, T. (1995). Human resource strategies and firm performance: What do we know and where do we need to go? The International Journal of Human Resource Management, 6(3), 656-670. https://doi.org/10.1080/09585199500000041

Furnham, A., \& Gunter, B. (1993). Corporate Assessment. Auditing a Company's Personality. Organization Studies, 14(4), 640-640. https://doi.org/10.1177/017084069401500421

Golung, H. D. (2013). Relationship between Compensation, Work Environment, Organizational Culture, and Employee Performance at Hotel Sedona Manado. Jurnal EMBA, 1(4), 811-819.

Hartman, R. J., Kurtz, E. M., \& Moser, E. K. (1994). Incentive programs to improve transit employee performance (Ser. 3). Washington, D.C.: National Academy Press.

Heathfield, S. M. (2019, May 14). What Are Salary and Salary Requirements of Job Candidates? Retrieved from http://humanresources.about.com/od/glossarys/g/salary.htm

Hellriegel, D., Jackson, S. E., \& Slocum, J. W. (2005). Management. Singapur: Thomson Learning.

Hofstede, G., \& Bond, M. H. (1988). The Confucius connection: From cultural roots to economic growth. Organizational Dynamics, $16(4), \quad$ 5-21. https://doi.org/10.1016/0090-2616(88)90009-5

Hofstede, G., Neuijen, B., Ohayv, D. D., \& Sanders, G. (1990). Measuring Organizational Cultures: A Qualitative and Quantitative Study Across Twenty Cases. Administrative Science Quarterly, 35(2), 286-316. https://doi.org/10.2307/2393392

Ivancevich, J. M., \& Glueck, W. G. (1989). Foundations of personnel: Human resource management. Homewood, Ill: Irwin.

Kim, P. S., Pindur, W., \& Reynolds, K. (1995). Creating a new organizational culture: The key to total quality management in the public sector. International Journal of Public Administration, 18(4), 675-709. https://doi.org/10.1080/01900699508525027

Kline, S., \& Hsieh, Y. J. (2007). Wage Differentials in the Lodging Industry. Journal of Human Resources in Hospitality \& Tourism, 6(1), 69-84. https://doi.org/10.1300/J171v06n01_04

Lazear, E. (1999). Personnel Economics: Past Lessons and Future Directions Presidential 
Address to the Society of Labor Economists, San Francisco, May 1, 1998. Journal of Labor Economics, 17(2), 199-236. https://doi.org/10.1086/209918

Louis, M. R. (1981). A cultural perspective on organizations: The need for and consequences of viewing organizations as culture-bearing milieux. Human Systems Management, 2(4). 246-258. 10.3233/HSM-1981-2403.

Luthans, F. (2011). Organizational behavior: An evidence-based approach (12th ed.). Boston: McGraw-Hill.

Malhotra, N., Budhwar, P., \& Prowse, P. (2007). Linking rewards to commitment: An empirical investigation of four UK call centres. The International Journal of Human Resource Management, 18(12), 2095-2128. https://doi.org/10.1080/09585190701695267

Martins, E., \& Terblanche, F. (2003). Building organisational culture that stimulates creativity and innovation. European Journal of Innovation Management, 6(1), 64-74. https://doi.org/10.1108/14601060310456337

Martocchio, J. J. (2011). Strategic compensation: A human resource management approach (6th ed.). Upper Saddle River, NJ: Pearson.

Messner, W. (2013). Effect of organizational culture on employee commitment in the Indian IT services sourcing industry. Journal of Indian Business Research, 5(2), 76-100. https://doi.org/10.1108/17554191311320764

Nazir, O., \& Islam, J. U. (2017). Enhancing organizational commitment and employee performance through employee engagement. South Asian Journal of Business Studies, 6(1), 98-114. https://doi.org/10.1108/SAJBS-04-2016-0036

Noe, R. A., Hollenbeck, J. R., Gerhart, B., \& Wright, P. M. (2013). Human resource management: Gaining a competitive advantage (8th ed.). New York: McGraw-Hill/Irwin.

Pattanayak, B. (2014). Human resource management (4th ed.). Delhi: PHI Private Limited.

Pitts, C. (1995). Motivating your organization: Achieving business success through reward and recognition (1st ed.). London: McGraw-Hill Book.

Ritchie, M. (2000). Organizational culture: An examination of its effect on the internalization process and member performance. Southern Business Review, 25(2), 1-13.

Rousseau, D. M., \& Tijoriwala, S. A. (1998). Assessing psychological contracts: Issues, alternatives and measures. Journal of Organizational Behavior, 19(S1), 679-695. https://doi.org/10.1002/(SICI)1099-1379(1998)19:1+<679::AID-JOB971>3.0.CO;2-N

Rue, L. W., Ibrahim, N. A., \& Byars, L. L. (2016). Human resource management (11th ed.). New York: McGraw-Hill Education.

Schein, E. H. (2010). Organizational culture and leadership (4th ed.). San Francisco: Jossey-Bass.

Schiller, Z. (1996). A Model Incentive plan gets Caught in a vise. Business Week: 89-90. 


\section{Macrothink}

International Journal of Human Resource Studies

ISSN 2162-3058 2019, Vol. 9, No. 3

Slocum, J. W., \& Hellriegel, D. (2011). Principles of organizational behavior (13th ed.). Mason, OH: South-Western.

Smircich, L. (2017). Concepts of Culture and Organizational Analysis. The Anthropology of Organisations, 255-274. https://doi.org/10.4324/9781315241371-20

Tichy, N. M. (1982). Managing change strategically: The technical, political, and cultural keys. Organizational dynamics, 11(2), 59-80. https://doi.org/10.1016/0090-2616(82)90005-5

Tsai, K., \& Wang, J. (2005). Benefits offer no advantage on firm productivity? Personnel Review, 34(4), 393-405. https://doi.org/10.1108/00483480510599743

\section{Copyright Disclaimer}

Copyright for this article is retained by the author(s), with first publication rights granted to the journal.

This is an open-access article distributed under the terms and conditions of the Creative Commons Attribution license (http://creativecommons.org/licenses/by/4.0/). 